Periodica Polytechnica Architecture, 50(2), pp. 132-138, 2019

\title{
Product Service Systems in Construction Supply Chains
}

\author{
Niclas Andersson ${ }^{1 *}$, Jerker Lessing ${ }^{2}$ \\ 1 Department of Materials Science and Applied Mathematics, Faculty of Technology and Society, Malmö University, , \\ Nordenskioldsgatan 1, S-205 06 Malmö, Sweden \\ 2 Civil and Environmental Engineering Department, Stanford Engineering, Stanford University, 473 Via Ortega, MC: 4020, \\ Stanford, CA 94305, USA \\ * Corresponding author, e-mail: niclas.andersson@mau.se
}

Received: 20 June 2018, Accepted: 12 February 2019, Published online: 28 November 2019

\begin{abstract}
The shipbuilding, automotive and aerospace industries are examples of industries offering product service systems (PSS) to their customers, i.e. they combine physical products with services to add increased value. While product service systems are well established in many manufacturing industries, it has barely emerged in the fragmented and project-based organisation of construction. The objective of this study is to identify and critically review examples of product service systems in construction supply chains, with the purpose of describing how it challenges prevailing business systems and organisation of construction work. The study rests upon two case studies carried out at Gyproc Saint-Gobain in Denmark and Celsa Steel Service in Sweden. The findings reveal significant challenges related to the implementation and marketing of the product service systems provided. Companies that develop and expand their business offers by providing new product service systems tend to find themselves operating in two parallel market segments, i.e. the traditional market of construction components and the new market of product service systems. The PSS-offers reviewed in the case studies show a strong focus and emphasis on the development of the offer and the operational platform, while the companies' market positions remain unchanged. Thus, the case study companies organise and operate their businesses and market relations as before the implementation of the product service system. The conclusion is that development and implementation of product service systems in construction supply chains requires awareness in the companies' offer of products and services, well-established operational platforms, and particularly, a renewed market position.
\end{abstract}

\section{Keywords}

product service system, operational platform, market position, industrialised construction

\section{Introduction}

A product is the result of a repetitive process that utilises a pre-developed structure of solutions for design and production (Meyer and Lehnerd, 2011). The product approach is fundamentally different to the traditional project-based construction, where buildings are produced as uniquely designed, one-of-a-kind solutions, executed by temporary teams in loosely coupled supply chains (Gann and Salter, 2000; Gosling and Naim, 2009). A product-oriented company specialises in offering a specific range of products that allow for repetitions and continuous improvements over time, in order to establish an efficient manufacturing process and supply chain. Production methods, technical solutions and sub-systems can be predefined and enable efficient end-product configuration, due to the limitations of the scope of the product (Ulrich and Eppinger, 2011).
Product platforms constitute systematic structures of subsystems used for development and production of derivative products (Meyer and Lehnerd, 2011). Robertson and Ulrich (1998) describe product platforms according to four distinctive aspects, namely components, processes, knowledge, and finally, people and relationships. Production platforms are optimised for efficient delivery by executing design, production and supply of materials in cooperative and recurring processes by integrated teams engaged on a long-term basis. Further, product and platform development requires a clear perception of the customer's needs, requirements and priorities in order to tailor attractive and competitive concepts (Ulrich and Eppinger, 2011) aimed at certain market segments (Meyer and Lehnerd, 2011). The specific importance of including customer focus in a 
product-oriented production system is also emphasised by Barlow and Ozaki (2003), Barlow et al. (2003) as well as Lessing (2015). These authors conclude that product-orientation requires long-term investments in platform development, production facilities and accordingly, a clear understanding of the customers' needs for the design and development of product concepts is crucial.

A product is composed of a physical part, i.e. the tangible product that is manufactured and offered to customers, and an intangible part that consists of the various services that are offered to the customers (Tukker and Tischner, 2006). Offerings that systematically combine both tangible and intangible products are commonly referred to as product service systems (PSS). The concept of PSS has been defined by several authors, e.g. Mont (2002), Manzini and Vezzoli (2003) and Tukker and Tischner (2006), only with minor variations in their definitions. The common understanding of PSS is that it represents a systematic way of structuring a combination of tangible products, services and the networks needed to satisfy customer needs. Manzini and Vezzoli (2003), defines a product service system as a combination of physical products and services that affects the company's offerings and business scope:

"A Product Service System is an innovation strategy, shifting the business focus from designing (and selling) physical products only, to designing (and selling) a system of products and services which are jointly capable of fulfilling specific client needs".

A PSS can be dominated either by the product, with only limited supplementary service, or by the service complemented by a minor physical product. Three basic types of product service systems can be outlined, namely the product-oriented, the use-oriented and the result-oriented product-service systems (Baines et al., 2007), see Fig. 1.

PSS is emerging significantly in many manufacturing industries, and a driving force for this development is that PSS offers extended possibilities for customisation (Mont, 2002). Another important aspect of a PSS-offer

\begin{tabular}{|c|c|c|c|c|}
\hline \multirow[b]{2}{*}{$\begin{array}{l}\text { Value } \\
\text { mainly } \\
\text { in } \\
\text { product } \\
\text { content }\end{array}$} & \multicolumn{3}{|c|}{ Product Service System } & \multirow[b]{2}{*}{$\begin{array}{l}\text { Value } \\
\text { mainly } \\
\text { in } \\
\text { service } \\
\text { content }\end{array}$} \\
\hline & \multicolumn{3}{|c|}{$\begin{array}{lr}\text { Product } & \begin{array}{r}\text { Service content } \\
\text { (intangibel) } \\
\text { content (tangibel) }\end{array} \\
\end{array}$} & \\
\hline $\begin{array}{c}\text { Pure } \\
\text { Product }\end{array}$ & $\begin{array}{l}\text { Product- } \\
\text { oriented }\end{array}$ & $\begin{array}{c}\text { Use- } \\
\text { oriented }\end{array}$ & $\begin{array}{l}\text { Result- } \\
\text { oriented }\end{array}$ & $\begin{array}{l}\text { Pure } \\
\text { Service }\end{array}$ \\
\hline
\end{tabular}

Fig. 1 Product and service focus of product service system (based on (Tukker and Tischner, 2006)). is that it enables the establishment of long-term relationships between the PSS-supplier and its customers, as the service-offer can extend throughout the whole lifecycle of the physical product (Manzini and Vezzoli, 2003). Compared to the alternative of a biased focus on either products or services, a PSS offer enhances business opportunities and potentially improved revenue (Kindström, 2010). Long-term business relations also help to promote sustainability, as products with reduced energy consumption, more durable materials and technical solutions, for example, will reduce costs for maintenance and repairs and consequently, provide a chance for improved profit for the PSS-supplier (Roy, 2000).

The shipbuilding, automotive, aerospace and other manufacturing industries show an increased focus on combining physical products with services (Baines et al., 2007). For example, the Norwegian shipping company of Nor Lines (2018), has what they call a "Power by the hour" service agreement with Rolls-Royce (2018), which includes the service and maintenance of two gas-powered sea vessels of Nor Lines. Rolls-Royce offers similar service agreements to airline companies. Atlas Copco (2018), a Swedish industrial company that manufactures industrial tools and equipment such as air compressors, has developed a new offering called airLET (2018). This is a pay-as-you-go service where the customers pay a fixed monthly service charge and a variable fee based on the amount of compressed air that the customer has consumed. Accordingly, the combination of products and services could provide similar opportunities for perhaps manufacturers of building materials and industrialised construction companies to expand their offerings.

\subsection{Problem statement}

While product service systems are well established in many manufacturing industries, it has barely emerged in the construction industry. Construction is characterised as an industry producing complex one-of-a-kind products, in temporary organisations using mainly onsite production methods (Gann and Salter, 2000; Gosling and Naim, 2009). Supply chain integration is scarce due to a fragmented process dominated by short-term relations between the project actors (Cox and Ireland, 2002). Temporary design teams from different consulting firms carry out the design, and a variety of contractors and subcontractors use project-specific production methods on site (Naim and Barlow, 2003). Thus, the traditional organisation of construction work offers limited incentives and possibilities 
to establish systematically repeated and improved production methods and design solutions in a long-term business relationship (Dubois and Gadde, 2010).

As the implementation and experience of product service systems in construction is still limited, there is little research done in the field. Some researchers, however, touch upon the topic of PSS. For example, Brady et al. (2005) explore the opportunities and obstacles for applying so-called integrated solutions in the construction industry. These integrated solutions are described as combinations of products and services that address customers' requirements and consequently, are conceptually similar to PSS. Brady et al. (2005) state that companies need to structure their business around repeatability in terms of both technical systems and services offered, as well as standardised processes, in order to successfully implement integrated solutions, i.e. PSS. Further, Lessing (2015) claims that PSS provides an opportunity for industrialised construction companies to develop their offering and create new business models and new sources of income. Industrialised construction, including prefabrication of more or less complex building systems and elements, and the manufacturing of building material and equipment, constitutes the manufacturing part of construction. For the same reasons as for other manufacturing industries, implementation of product service systems could potentially provide new and more extensive business opportunities for this industrial part of the construction industry.

\subsection{Purpose and objectives}

The objective of this study is to identify and critically review examples of product service systems in construction supply chains, with the purpose of describing how it challenges prevailing business systems and the organisation of construction work.

\section{Method}

The study rests upon a literature study and empirical data collected in two case studies. The first case was carried out together with Celsa Steel Service in Sweden, referred to as Celsa in this context (Celsa, 2018); the other case was in collaboration with Gyproc Saint-Gobain in Denmark (Saint-Gobain, 2018), referred to as Gyproc. The case studies were carried out to identify and critically review examples of product service systems and to outline and describe the business relations, the value chains and the products and services offered by the two companies.

The collection of empirical data was primarily done by semi-structured interviews, a study visit to the production facility and by relevant documentation of the companies as well as their respective products and services. Altogether, eight interviews were carried out with key representatives from the two companies. All interviews were recorded and transcribed. The transcriptions were sent back to the respective respondents for proofreading and the possibility for supplements and corrections in the documentation.

\section{Product service systems in construction}

Research on business models for industrialised house building and construction companies is scarce (Pan and Goodier, 2012), but emerging. Brege et al. (2014) were some of the first to present an evaluation of business models' companies in industrialised construction. Other recent research contributions on business models in this field have been presented by Höök et al. (2015) and Lessing and Brege (2015). Brege et al. (2014) made a central contribution in terms of a business model framework that consists of three cornerstones required for describing an industrialised house-building company's business model, namely the operational platform, the market position and the offering, see Fig. 2. These three components of the business model framework have been selected as the basis of analysis of the product service systems in this study.

The offering, in this case, represents the PSS-value proposition, i.e. the tangible part of a product and the intangible part of a service offer. The systematic development and structuring of a combination of products and services in a PSS-offer must satisfy customer needs, i.e. have an existing or create a new market place, and will affect the company's business concept (Manzini and Vezzoli, 2003).

The operational platform describes the company's complex structure of resources, competencies and production facilities that are integrated and organised to enable repetitive production of a selected range of products and services. Besides the production facilities, the operational platform also includes activities and operations such as management, planning, design, supply chain, information and communication systems as well as research and development (Liker, 2004; Ohno, 1988; Bellgran and

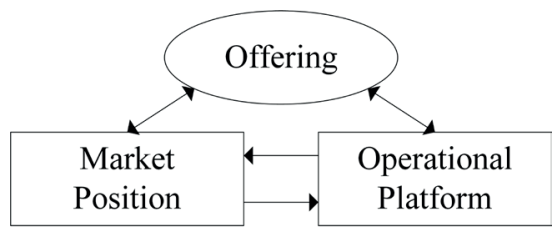

Fig. 2 The business model framework used as the basis of analysis in this study (Brege et al., 2014). 
Säfsten, 2009). Thus, the operational platform provides the foundation from which the PSS-offer derives.

The market position of the business model framework describes the company's role in the market place and the supply chain. As mentioned previously, an important aspect of PSS-offerings is that it supports long-term relationships between the PSS-supplier and its customers, as the service offer can extend throughout the lifecycle of the tangible product (Manzini and Vezzoli, 2003). The business relations between clients and suppliers in construction is often organised by framework agreements, which allows the client to invite tenders from suppliers of products and services over a longer period instead of initiating a new procurement process in every project (Designing Buildings Ltd, 2018).

The development and design of a PSS-offering, as described above, rests upon the operational platform and its production facilities, supply chain. A good understanding of client needs, potential competitors and market conditions are also important in order to design a successful PSS-offering. Consequently, the three components of the business model framework are strongly interrelated.

\subsection{Case 1: Celsa Steel Service - reinforcement cages}

Celsa (Celsa, 2018), one of seven companies of the Celsa Group (Celsa Group, 2018), is a leading European manufacturer of a wide range of reinforcement solutions such as detailing, carpet reinforcement, prefabricated welded products, pile cages, just-in-time delivery and client management systems.

\subsubsection{The PSS-offering}

The PSS-offering described in the Celsa case study includes prefabricated reinforcement cages for foundations, pier footings, beams, and pillars. The additional services include structural reinforcement design in 3D, quantity take-offs, industrial (i.e. automated) prefabrication and logistical services. The added values of the PSSoffering that Celsa wants to offer to their customers, are prominent technical design solutions, improved working conditions (i.e. health and safety), time and cost savings, quality improvements, and logistical services, which are accomplished when moving the hazardous and tedious reinforcement work from the construction site to prefabrication in an industrial and automated production facility.

Celsa's PSS represents an offering where the product attains the primary focus, following the categorisation of product and service focus of PSS-offerings presented in Fig. 1.

\subsubsection{Operational platform}

The operational platform of Celsa consists of a highly automated industrial facility producing all the various prefabricated reinforcement products, such as the reinforcements cages highlighted in this case study. The service part of the operational platform supports the production line and provides services in terms of 3D-design, quality control and clash detection, logistical services and an information management system. Besides this, Celsa has developed its online ordering service.

\subsubsection{Market position}

Celsa has two principal types of clients and operates in two parallel lines of business. Housebuilding and construction contractors provide one important type of client, and suppliers of prefabricated concrete elements constitute the other.

Celsa's traditional line of business is the production and selling of raw standard reinforcement products such as bars, coils and wire rods sold by tonnage. The other line of business represents the refined prefabricated reinforcement products and additional services as described in the PSSoffering in this study. The development of PSS-offerings and its added value to their customers is one way for Celsa to answer the increasing competition from international suppliers of raw, unrefined, reinforcement products.

Contractors, as well as suppliers of prefabricated reinforcement, are customers in both lines of business, i.e. the traditional standard and the prefabricated reinforcement solutions. Celsa establishes framework agreements with the purchasing departments of their respective main customers, typically on a yearly basis, which defines the scope, geographical locations, pricing mechanism for the standard set of products and other contract conditions. However, the orders of reinforcement products and services from contractors come directly from the construction managers in the building and construction projects.

\subsubsection{Review of Celsa's PSS-offering}

The PSS-offer of Celsa represents a resource-based, i.e. an inside out (Prahalad and Hamel, 1990) business approach based on the company's technological knowledge and competencies, production facilities, information and logistical infrastructure and other resources. An essential requirement for this approach is the ability to exploit the internal and external competencies, but also to find a market demand and to create value for their customers (Wernerfelt, 1984; Teece et al., 1997). 
Celsa presents a competitive and attractive PSSoffering. However, Celsa has not yet fully managed to create a strong market demand for their PSS. The bidding procedures go with tradition, where contractors continue to ask for raw reinforcement products for single building or construction projects and select their reinforcement suppliers by lowest price per tonnage. Accordingly, Celsa still competes with other suppliers by lowest prices on raw reinforcement products, and the expected competitive advantage of PSS-offering does not fully occur. The business relation between contractors and Celsa is dominated by the long-term framework agreements, which regulate the pricing for standard reinforcement products. The prefabricated reinforcement solutions provided by the PSS-offering is unique for each project, and consequently, cannot be priced in a framework agreement as easily as standard reinforcement products. The PSS-offer is reduced to a potential after-sale for Celsa if they win the original bid by lowest price per tonnage.

Thus, this is an example of where the market position and business models are not renewed in parallel with the development and implementation of the PSS-offering. Instead, Celsa still operates in the traditional market place of raw reinforcement products, and consequently, face difficulties to promote and market their PSS-offering.

\subsection{Case 2: Gyproc - the XRoc wallboard system}

The Gyproc case reviews the product and services related to the new XRoc wallboard system, initially introduced in a hospital building project in Denmark called "Det Nye Rigshospital” (in Danish) (Region Hovedstaden, 2018). The case study is delimited to the PSS-offering presented in this particular project.

\subsubsection{The PSS-offering}

This PSS-offering is represented by Gyproc's new wallboard system called XRoc and its related services in terms of technical design, assembly instruction and performance validation. The XRoc wallboard is specially designed to absorb ionising radiation (e.g. X-Rays) from CT scanners and similar devices that are frequently used in hospitals. The XRoc wall system is free from lead, which significantly improves the health and safety aspects compared to the handling, erection, as well as the demolition, of traditional lead-based wallboards.

Concerning the product and service categorisation of PSS-offerings presented in Fig. 1, the XRoc system can be considered an offering where the service attains the principal focus. For Gyproc, it is of the greatest importance that the result of the XRoc wallboard systems in the hospital project fulfils all the national rules and regulations on radiation.

\subsubsection{Operational platform}

The international company of Gyproc is one of about 1000 companies in the global Saint-Gobain Group (SaintGobain, 2018). Gyproc, with about 12000 employees operating in 56 countries, has a long experience in developing, manufacturing and distribution of lightweight gypsum plasterboard systems for interior walls and ceilings and other building materials (Gyproc Saint-Gobain, 2018). Gyproc has well-developed production facilities, communication and information infrastructures, and logistical networks; consequently, the operational platform must be considered well developed and very competitive. The XRoc wallboard system is a result of internal research and development carried within the Saint-Gobain Group.

\subsubsection{Market position}

Gyproc's business partner in the hospital project of this case study is delimited to a wholesaler of building materials. The Contractor orders the XRoc system as well as traditional gypsum boards and other goods provided by Gyproc directly from the wholesaler. Thus, Gyproc has a remote market position, with no direct business relations to the contractor or other actors of the building project.

\subsubsection{Review of Gyproc's PSS-offering}

Gyproc's PSS-offer represents a market-based, outside-in, business approach where the contractor's demands and needs provide the starting point. The contractor turned to Gyproc during the hospital project asking for help and support with design and validation of technical solutions for ventilation ducts, electrical switches, walls plugs, doorcases and other connections through the XRoc wallboard system. Traditional lead-based solutions were not allowed in the project due to client demands.

It is perfectly in line with Gyproc's general business idea, as well as with the PSS-offering of the XRoc system, to develop and market technical solutions for their customers. However, Gyproc's market position in the hospital project, in this case, did not support this strategy. As Gyproc had no business relationship with the contractor of the building project, there were questions and uncertainties raised about the liabilities and warranties of the technical solutions Gyproc should provide. After considering 
how to act, Gyproc did develop and present the technical solutions and validation of the results that were asked for by the client. The market position and contractual arrangements, in this case, did not allow Gyproc to be fully reimbursed for their services. Gyproc needs to establish a market position higher up the value chain in order to support the PSS-offering of the XRoc wallboard system.

\section{Conclusion}

The two case studies reveal significant challenges related to the implementation and marketing processes of product service systems. The companies that are developing and expanding their business offers by providing new product service systems find themselves operating in two parallel market segments, i.e. the traditional market of construction components and the new market of product service

\section{References}

Atlas Copco (2016) Atlas Copco Introduces airLET: Compressed air on demand, [online] Available at: https://www.atlascopco.com/ en-uk/compressors/News-and-stories/introducing-airLET-compressed-air-on-demand [Accessed: 14 June 2018]

Atlas Copco (2018) Atlas Copco, [online] Available at: www.atlascopco. com/sv-se [Accessed: 14 June 2018] (in Swedish)

Baines, T. S., Lightfoot, H. W., Evans, S., Neely, A., Greenough, R., Peppard, J. (2007) "State-of-the-art in product-service systems", Journal of Engineering Manufacture, 221(10), pp. 1543-1552. https://doi.org/10.1243/09544054JEM858

Barlow, J., Childerhouse, P., Gann, D., Hong-Minh, S., Naim, M., Ozaki, R. (2003) "Choice and delivery in housebuilding: lessons from Japan for UK housebuilders", Building Research \& Information, 31(2), pp. 134-145. https://doi.org/10.1080/09613210302003

Barlow, J., Ozaki, R. (2003) "Achieving 'Customer Focus' in Private Housebuilding: Current Practice and Lessons from Other Industries", Housing Studies, 18(1), pp. 87-101. https://doi.org/10.1080/0267303032000076858

Bellgran, M., Säfsten, E. K. (2009) "Production development: design and operation of production systems", Springer, New York, London.

Brady, T., Davies, A., Gann, D. (2005) "Can integrated solutions business models work in construction?", Building Research \& Information, 33(6), pp. 571-579. https://doi.org/10.1080/09613210500285064

Brege, S., Stehn, L., Nord, T. (2014) "Business models in industrialized building of multistorey houses", Construction Management and Economics, 32(1-2), pp. 208-226. https://doi.org/10.1080/01446193.2013.840734

Celsa (2018) Celsa, [online] Available at: www.celsa-steelservice.se/ foretaget/, [Accessed: 05 February 2018] (in Swedish)

Celsa Group (2018) Celsa Group, [online] Available at: www.celsagroup. com/ [Accessed: 13 March 2018] systems. The reviewed product service systems in the two case studies show a strong focus and emphasis on the development of the PSS-offering and the operational platform, while the companies' role and market position remain unchanged. Thus, the case study companies organise and operate their businesses and market relations as before the implementation of the product service system. The conclusion is that development and implementation of product service systems in construction supply chains require awareness in the companies' offer of products and services, and well-established operational platforms, but above all, a renewed market position. These findings are well in accordance with Brady et al. (2005), who state that a PSS-approach requires maturity and balance in the PSSoffering, operational capabilities and a surrounding market that is open for the PSS-offering.

Cox, A., Ireland, P. (2002) "Managing Construction Supply Chains: The Common Sense Approach", Engineering, Construction and Architectural Management, 9(5-6), pp. 409-418. https://doi.org/10.1108/eb021235

Designing Buildings Ltd. (2018) Designing Buildings Wiki, [online] Available at: www.designingbuildings.co.uk/wiki/Framework_ contract [Accessed: 15 June 2018]

Dubois, A., Gadde, L. E. (2010) "The construction industry as a loosely coupled system: implications for productivity and innovation", Construction Management and Economics, 20(7), pp. 621-631. https://doi.org/10.1080/01446190210163543

Gann, D. M., Salter, A. J. (2000) "Innovation in project-based, service-enhanced firms: the construction of complex products and systems", Research Policy, 29(7-8), pp. 955-972. https://doi.org/10.1016/S0048-7333(00)00114-1

Gosling, J., Naim, M. M. (2009) "Engineer-to-order supply chain management: A literature review and research agenda", International Journal of Production Economics, 122(2), pp. 741-754. https://doi.org/10.1016/j.ijpe.2009.07.002

Gyproc Saint-Gobain (2018) About Gyproc [online] Available at: www. gyproc.in/company-profile [Accessed 27 March 2018]

Höök, M., Stehn, L., Brege, S. (2015) "The development of a portfolio of business models: a longitudinal case study of a building material company", Construction Management and Economics, 33(5-6), pp. 334-348.

https://doi.org/10.1080/01446193.2015.1075052

Kindström, D. (2010) "Towards a service-based business model - Key aspects for future competitive advantage", European Management Journal, 28(6), pp. 479-490. https://doi.org/10.1016/j.emj.2010.07.002

Lessing, J. (2015) "Industrialised House-Building, Conceptual Orientation and strategic perspectives", PhD Thesis, Lund University. 
Lessing, J., Brege, S. (2015) "Business models for product-oriented house-building companies - experience from two Swedish case studies", Construction Innovation, 15(4), pp. 449-472. https://doi.org/10.1108/CI-02-2015-0009

Liker, J. K. (2004) "The Toyota Way: 14 Management Principles from the World's Greatest Manufacturer", McGraw-Hill, New York, USA.

Manzini, E., Vezzoli, C. (2003) "A strategic design approach to develop sustainable product service systems: Examples taken from the 'environmentally friendly innovation' Italian prize", Journal of Cleaner Production, 11(8), pp. 851-857.

https://doi.org/10.1016/S0959-6526(02)00153-1

Meyer, M. H., Lehnerd, A. P. (2011) "The Power of Product Platforms: Building Value and Cost Leadership", The Free Press, New York, USA.

Mont, O. K. (2002) "Clarifying the Concept of Product-Service System", Journal of Cleaner Production, 10(3), pp. 237-245. https://doi.org/10.1016/S0959-6526(01)00039-7

Naim, M., Barlow, J. (2003) "An Innovative Supply Chain Strategy for Customised Housing", Construction Management and Economics, 21(6), pp. 593-602. https://doi.org/10.1080/0144619032000134129

Nor Lines (2018) Nor Lines, [online] Available at: https://norlines.no/ [Accessed: 14 June 2018] (in Norwegian)

Ohno, T. (1988) "Toyota Production System: Beyond Large-Scale Production", Productivity Press, New York, USA.

Pan, W., Goodier, C. (2012) "House-Building Business Models and OffSite Construction Take-Up", Journal of Architectural Engineering, 18(2), pp. 84-93.

https://doi.org/10.1061/(ASCE)AE.1943-5568.0000058
Prahalad, C. K., Hamel, G. (1990) "The Core Competence of the Corporation", Harvard Business Review, 68(3), pp. 79-91.

Region Hovedstaden (2018) Det nye Rigshospital, [online] Available at: www.rigshospitalet.dk/nythospitalblegdamsvej/Sider/default.aspx [Accessed: 28 March 2018] (in Danish)

Robertson, D., Ulrich, K. (1998) "Planning for Product Platforms", Sloan Management Review, 39(4), pp. 19-31.

Rolls-Royce (2018) Rolls-Royce, [online] Available at: www.rolls-royce. com/products-and-services.aspx [Accessed 14 June 2018]

Roy, R. (2000) "Sustainable product-service systems", Futures, 32(3-4), pp. 289-299.

https://doi.org/10.1016/S0016-3287(99)00098-1

Saint-Gobain (2018) Om Saint-Gobain, [online] Available at: http:/ www.saint-gobain.dk/, [Accessed: 03 May 2018] (in Danish)

Teece, D. J., Pisano, G., Shuen, A. (1997) "Dynamic Capabilities and Strategic Management", Strategic Management Journal, 18(7), pp. 509-533.

https://doi.org/10.1002/(SICI)1097-0266(199708)18:7<509::AIDSMJ882>3.0.CO;2-Z

Tukker, A., Tischner, U. (2006) "Product-services as a research field: past, present and future. Reflections from a decade of research", Journal of Cleaner Production, 14(17), pp. 1552-1556. https://doi.org/10.1016/j.jclepro.2006.01.022

Ulrich, K. T., Eppinger, S. D. (2011) "Product Design and Development", McGraw-Hill, New York, USA.

Wernerfelt, B. (1984) "A resource-based view of the firm", Strategic Management Journal, 5(2), pp. 171-180. https://doi.org/10.1002/smj.4250050207 